\title{
Parasitic copepods of marine fish cultured in Japan: a review
}

\author{
Kazuya Nagasawa* \\ Graduate School of Biosphere Science, Hiroshima University, Hiroshima, Japan
}

(Received 22 September 2014; accepted 4 February 2015; first published online 29 June 2015)

\begin{abstract}
This paper reviews aspects of the biology of copepods infecting marine fish commercially cultured at fish farms or held as broodstock at governmental hatcheries in Japan. In total, 20 species of parasitic copepods have been reported from these fish: they are mostly caligids (12 spp.), followed by lernaeopodids ( $4 \mathrm{spp}$.), pennellid (1 sp.), chondracanthid (1 sp.), taeniacanthid (1 sp.), and unidentified species (1 sp.). The identified copepods are: Caligus fugu, C. lagocephalus, C. lalandei, C. latigenitalis, C. longipedis, C. macarovi, C. orientalis, C. sclerotinosus, C. spinosus, Lepeophtheirus longiventralis, L. paralichthydis, L. salmonis (Caligidae); Alella macrotrachelus, Clavella parva, Parabrachiella hugu, P. seriolae (Lernaeopodidae); Peniculus minuticaudae (Pennellidae); Acanthochondria priacanthi (Chondracanthidae); and Biacanthus pleuronichthydis (Taeniacanthidae). The fish recorded as hosts include carangids (4 spp.), sparids (2 spp.), monacanthids (2 spp.), salmonids (2 spp.), scombrid (1 sp.), tetraodontid (1 sp.), pleuronectid (1 sp.), paralichthyid (1 sp.), and trichodontid (1 sp.). Only five species (C. orientalis, L. longiventralis, L. salmonis, C. parva and A. priacanthi) parasitize farmed fish in subarctic waters, while all other species (15 spp.) infect farmed fish in temperate waters. No information is yet available on copepods from fish farmed in subtropical waters. Three species of Caligus (C. fugu, C. sclerotinosus and C. longipedis) are serious pests in aquaculture of Japanese pufferfish (Takifugu rubripes), red seabream (Pagrus major), and striped jaw (Pseudocaranx dentex), respectively. Due to its one-host life cycle that is unique among pennellids, $P$. minuticaudae is considered as a potentially serious pest with further development of aquaculture of its filefish hosts, threadsail filefish (Stephanolepis cirrhifer) and black scraper (Thamnaconus modestus). Infection of farmed salmonids by $L$. salmonis is not a serious problem in Japan.
\end{abstract}

Keywords: Copepoda; sea lice; fish parasite; aquaculture

\section{Introduction}

The Japanese Archipelago is located in East Asia, consisting of four major islands (Hokkaido, Honshu, Shikoku, and Kyushu) and over 6800 islets. This archipelago is surrounded by four seas (western North Pacific Ocean, East China Sea, Sea of Japan, and Sea of Okhotsk) and extends over $3000 \mathrm{~km}$ from Hokkaido in the north to the Ryukyu Islands in the south. The seas around Japan are strongly affected by ocean currents (two warm-water currents, the Kuroshio and its branch, the Tsushima Current, and two cold-water currents, the Oyashio and the East Sakhalin Current) and are largely divided into three waters: subarctic, temperate, and subtropical waters. The subarctic waters exist off northern Honshu and Hokkaido and water temperature (WT) remains low because of the presence of the Oyashio and the East

\footnotetext{
*Email: ornatus@hiroshima-u.ac.jp
} 
Sakhalin Current. The temperate waters occupy a very wide area off three major islands (Kyushu, Shikoku, and central and western Honshu), and WT demonstrates typical seasonal changes (increase in spring and summer but decrease in autumn and winter), influenced by the Kuroshio and the Tsushima Current. The subtropical waters occur off the Ryukyu Islands and WT remains constantly high, strongly affected by the Kuroshio.

Marine fish culture is widely carried out in coastal waters of Japan, and mean annual production exceeded 250,000 metric tons (mt) between 2008 and 2012 (Statistics of fisheries 2014). The fish species cultured in Japan vary between subarctic, temperate, and subtropical regions. Due to constant low WT in subarctic waters, cold-water species, such as salmon and trout (Oncorhynchus spp.), are cultured. In temperate waters, a variety of marine fish species are cultured, and amberjacks (Seriola spp.), red seabream (Pagrus major), striped jack (Pseudocaranx dentex), Pacific bluefin tuna (Thunnus orientalis), Japanese pufferfish (Takifugu rubripes), and bastard halibut (Paralichthys olivaceus) are the main species used for farming. There is only a short history of marine fish culture in subtropical waters, where warm-water species, especially groupers (Epinephelus spp.), are farmed. In addition to these fish farmed in the three regions, some other species are cultured as broodstock at governmental hatcheries to produce their juveniles for stock enhancement programmes.

Copepods are known to parasitize cultured marine fish, and especially caligids, called sea lice, are one of the most serious pests in aquaculture industries in the northern and southern hemispheres: the global annual losses due to sea lice in salmonid culture are estimated to exceed US\$100 million (Johnson et al. 2004). In Japan, aquacultured marine fish also often harbour parasitic copepods, some of which cause serious disease condition and mortality in infected fish. This paper reviews various aspects of the biology of such parasitic copepods infecting those fish commercially cultured at fish farms or held as broodstock at hatcheries in Japan. The scientific and common names of the fish in this paper follow Froese and Pauly (2014).

\section{Parasitic copepods found in mariculture of Japan}

A total of 20 species have been found from marine fish cultured in Japan, consisting of 12 species in the Caligidae (commonly referred to as 'sea lice'), four species in the Lernaeopodidae, one species in the Pennellidae, one species in the Chondracanthidae, one species in the Taeniacanthidae, and one unidentified species in the 'Caligoida'. The identified copepods (in alphabetical order in each family) are: Caligus fugu, C. lagocephalus, C. lalandei, C. latigenitalis, C. longipedis, C. macarovi, C. orientalis, C. sclerotinosus, C. spinosus, Lepeophtheirus longiventralis, L. paralichthydis, L. salmonis (Caligidae); Alella macrotrachelus, Clavella parva, Parabrachiella hugu, P. seriolae (Lernaeopodidae); Peniculus minuticaudae (Pennellidae); Acanthochondria priacanthi (Chondracanthidae); and Biacanthus pleuronichthydis (Taeniacanthidae). The fish recorded as hosts include carangids (4 spp.), sparids (2 spp.), monacanthids (2 spp.), salmonids (2 spp.), scombrid (1 sp.), tetraodontid (1 sp.), pleuronectid (1 sp.), paralichthyid (1 sp.), and trichodontid (1 sp.).

Only five species (C. orientalis, L. longiventralis, L. salmonis, C. parva, and $A$. priacanthi) parasitize cold-water fish cultured in subarctic waters, while all other 
species (15 spp.) are found on fish farmed in temperate waters. No parasitic copepod from fish cultured in subtropical waters has yet been reported.

\section{Parasitic copepods of marine fish cultured in subarctic waters}

Two species of salmonids, coho salmon (Oncorhynchus kisutch) and rainbow trout (O. mykiss), are cultured in net pens in northern Japan. Coho salmon are more abundantly farmed than rainbow trout. Mean annual production of coho salmon in 2008-2012 was 10,638 mt (Statistics of fisheries 2014).

Lepeophtheirus salmonis and Caligus orientalis are known to infect the two salmonids (Nagasawa and Sakamoto 1993; Urawa et al. 1998; Ho and Nagasawa 2001) and rainbow trout (Urawa and Kato 1991), respectively. It is interesting to note that, unlike in Atlantic salmon (Salmo salar) culture in other regions of the world, such as Scotland, Ireland, Norway, and Canada (see Boxshall and Defaye 1993; Pike and Wadsworth 1999; Jones and Beamish 2011), L. salmonis is not a serious pest in Japanese coho salmon farming (Ho and Nagasawa 2001). This is because coho salmon are more resistant to $L$. salmonis than other salmon species (Johnson and Albright 1992); only young coho salmon are raised for seven to nine months from November, and all these salmon are harvested until July before WT becomes high in mid-summer; and while transmission of L. salmonis to coho salmon occurs only in fall from wild adult chum salmon (Oncorhynchus keta) migrating near the farming sites, all L. salmonis disappear from net-pen waters in mid-summer when no coho salmon are cultured (Ho and Nagasawa 2001). Rainbow trout show a slightly higher infection level of L. salmonis than coho salmon (Urawa et al. 1998; Ho and Nagasawa 2001), but as in coho salmon farming, this copepod has not been regarded as a serious pest in rainbow trout culture. Caligus orientalis was once reported to have heavily infected rainbow trout reared in brackish waters (Urawa and Kato 1991). However, no similar case of heavy infection with $C$. orientalis has been documented since, and this parasite is also not important in rainbow trout culture in Japan. Due to low abundance of L. salmonis and C. orientalis on farmed salmonids, no chemical control or treatment has been tried to eliminate these caligids in Japan. Very recently, based on molecular study using the materials from the North Atlantic and the North Pacific oceans, Skern-Mauritzen et al. (2014) recognized two subspecies in L. salmonis and named L. salmonis oncorhynchi (a new subspecies) for the Pacific L. salmonis. Detailed information on the biology of L. salmonis and C. orientalis is available in Nagasawa (2004).

Two species of copepods, Lepeophtheirus longiventralis and Clavella parva, have been reported each from spotted halibut (Verasper variegatus) (Pleuronectidae) (Ho et al. 2004) and gold-eye rockfish (Sebastes thompsoni) (Sebastidae) (Nagasawa et al. 2008), both of which are cultured in tanks as broodstock at hatcheries of governmental institutions in northern Japan. According to Ho et al. (2004), L. longiventralis was introduced along with wild-caught spotted halibut into the hatchery, where the chalimus stages of the copepod appeared on the host's body surface in late March and, after mating in early April, adult females moved to the host's gill cavities and carried egg sacs by mid-April. This indicates that L. longiventralis can easily reproduce and proliferate under artificial conditions. When the gills are infected by adult females, a lot of mucus is produced and surrounds the female's body. Due to the blood feeding of these females, heavily 
infected fish become anaemic and weak (Masato Aritaki, Fukuyama University, Fukuyama, Hiroshima, Japan, personal communication). The freshwater bath is effective in dislodging copepods from wild-caught fish before they are released into the rearing tank. Clavella parva is a fin parasite of golden-eye rockfish, occurring mainly on the dorsal and caudal fins (Nagasawa et al. 2008). This parasite was likely introduced into the hatchery along with the same fish species held in cages in natural waters. Infected fish showed no disease signs and no reduction in body weight and condition factor. Manual removal of copepods from the fins of infected fish is effective for control of this parasite: no further infection appeared after such action (Nagasawa et al. 2008).

Acanthochondria priacanthi was found on wild-caught broodstock candidates of Japanese sandfish (Arctoscopus japonicus) (Trichodontidae) used for seed production at a governmental hatchery in Hokkaido (Nagasawa and Takaya 2008). Copepods are usually confined to the inner surface of the host's operculum, but at high intensities (up to 47 copepods per fish) they expand their attachment sites to the buccal and branchial cavities, gill arches, and lower jaw. No work has been done on the biology of $A$. priacanthi infecting Japanese sandfish held at the hatchery.

\section{Parasitic copepods of marine fish cultured in temperate waters}

In total, 15 species of parasitic copepods have been reported from various marine fish cultured in temperate waters. Below are brief accounts for the copepods infecting the major farmed fish of different taxonomic groups.

\section{Copepods infecting amberjacks}

Amberjack culture has a long history and is the most important marine fish farming industry in Japan. Three species of amberjacks (Carangidae) are cultured: Japanese amberjack (Seriola quinqueradiata), greater amberjack ( $S$. dumerili), and yellowtail amberjack ( $S$. lalandi). Japanese amberjack are most abundantly farmed in floating net pens, followed by greater amberjack and yellowtail amberjack. Aquaculture production of these amberjacks during 2008-2012 exceeded 150,000 mt per year (Statistics of fisheries 2014).

Caligus spinosus infects both Japanese amberjack (Kubota and Takakuwa 1963, reported as 'Caligus sp. 1'; Fujita et al. 1968; Izawa 1969; Egusa 1983; Ogawa and Yokoyama 1998; Fukuda 1999; Ho et al. 2001; Cruz-Lacierda et al. 2011) and yellowtail amberjack (Nagasawa and Fukuda 2011) cultured in Japan. Another caligid Caligus lalandei also parasitizes these two amberjacks (Ho et al. 2001; Nagasawa and Fukuda 2011). Infection sites differ between these caligids: C. spinosus is found in the oral cavity of the host, especially on the gill arches and gill rakers, while $C$. lalandei occurs on the host's body surface. Previously, there was a taxonomic confusion of $C$. spinosus with $C$. aesopus, both of which infect amberjacks, but $C$. spinosus is now regarded as valid (Choe and Kim 2010). An unidentified species of Caligus was found on the body surface of farmed greater amberjack (Ogawa and Yokoyama 1998).

Wild-caught juveniles are used for Japanese amberjack farming: they are caught in the western North Pacific off western and central Japan in spring and early summer and transported alive to fish farms, where they are released into net pens. 
When caught at sea, these juveniles are found already infected by either $C$. spinosus or C. lalandei (Ho et al. 2001), and these copepods are introduced into net pens along with the wild-caught juveniles. Immediately after fish introduction into net pens in June, C. spinosus occurs on the host's body surface but in July and afterward it exclusively infects the gill region and becomes mature (Cruz-Lacierda et al. 2011). The infection level of $C$. spinosus is positively correlated with WT: its prevalence and mean intensity of infection are highest (90-100\% and 2.7-12.6 copepods per fish, respectively) during summer from July to September. Chalimi are found during this period, indicating that $C$. spinous reproduces in net pens during a high WT period. This caligid has seven larval (two naupliar, one copepodid, and four chalimus) stages in its development (Izawa 1969). No similar observation of seasonal occurrence and maturation has been made for $C$. lalandei at fish farms.

Heavy infection (up to over 4000 individuals per fish) by C. spinosus once induced mass mortalities of farmed Japanese amberjack (Fujita et al. 1968), but no gross pathological change or host mortality is usually associated with $C$. spinosus infection (Cruz-Lacierda et al. 2011). The freshwater bath is frequently employed at fish farms to lower the copepod's abundance on infected fish. No report has been published about the pathogenicity of $C$. lalandei, but it has been suggested that, due to its large body size (up to $8.63 \mathrm{~mm}$ long in the adult female), this species may cause a serious problem if there are outbreaks (Ho et al. 2001).

Parabrachiella seriolae is known to infect farmed Japanese amberjack (Yamaguti and Yamasu 1960; Ono 1984; Cruz-Lacierda et al. 2011). This parasite was originally described as Brachiella seriolae (Yamaguti and Yamasu 1960) but it is currently placed in Parabrachiella (see Piasecki et al. 2010). The copepod reported as 'Lerneopoda gen. sp. 1' (Kubota and Takakuwa 1963) or 'Eobrachiella elegans f. seriolae' (Ogawa and Yokoyama 1998) is identical with $P$. seriolae. The species is usually attached to the body surface of the host near the base of pectoral fins. The prevalence and mean intensity of $P$. seriolae on farmed Japanese amberjack remain low $(0-10 \%$ and up to 2.0 copepods per fish, respectively) throughout the year (CruzLacierda et al. 2011), but since the prevalence shows a positive correlation with WT and the majority of the copepods found are ovigerous females, it is considered to reproduce and infect Japanese amberjack in net pens. No serious damage caused by P. seriolae was observed (Cruz-Lacierda et al. 2011).

\section{Copepods infecting striped jack}

The fourth species of carangid cultured in Japan is striped jack (Pseudocaranx dentex). Its mean annual harvest was $2834 \mathrm{mt}$ during 2008-2012 (Statistics of fisheries 2014).

Caligus longipedis is an important pest in striped jack farming (Ogawa 1992; Fukuda 1999, 2001) and broodstock culture (Mushiake 1996) in Japan. Since the early 1960s, this caligid has been recognized as a parasite causing skin erosion in farmed striped jack (Kubota and Takakuwa 1963, reported as 'Caligus amplifurcus'). Copepods are found on the body surface and fins of the host. Almost all striped jack raised in net pens are infected by this caligid, and fish harbouring many copepods show abnormal behaviour, such as bursts of vigorous swimming near the water surface and rubbing their body against the rearing net. Such fish also lose their appetite and develop skin lesions, which can serve as portals of entry for secondary 
bacterial infections (Fukuda 2001). Two naupliar, one copepodid, and four chalimus stages are involved in the development of the species, and the life cycle is estimated to complete in about two weeks at $20^{\circ} \mathrm{C}$ (Ogawa 1992). Freshwater baths are repeatedly employed for control of the parasite, but it is very difficult to completely eliminate it at fish farms, because reinfection occurs soon after such freshwater baths (Fukuda 2001).

\section{Copepods infecting seabreams}

Two species of seabreams (Sparidae) are cultured in Japan: they are red seabream (Pagrus major) and blackhead seabream (Acanthopagrus schlegelii). Red seabream follows amberjacks in Japan's mariculture production with its mean annual production exceeding 65,000 mt between 2008 and 2012 (Statistics of fisheries 2014), while recent production of blackhead seabream is quite low, although the species was intensively cultured in the 1970s-1980s.

Caligus sclerotinosus is a skin parasite of farmed red seabream (Ho et al. 2004; Tanaka et al. 2013). Heavily infected fish (with up to about 500 copepods per fish) are observed from April to December (Tanaka et al. 2013). Copepods occur on the whole body surface, eyes, and all fins. Such fish exhibit scale exfoliation, abrasion and ulcerative lesions of the skin, and chipped fins. Other signs include dark body coloration, cloudy corneas, and lack of eyes. Daily fish mortality due to this parasite can reach $0.25 \%$ at fish farms. It is interesting to note that adults of $C$. sclerotinosus exhibit a positive phototaxis and thus their transfer between hosts can be affected by light conditions, which supports the fish farmers' observations that red seabream reared without shading above the net pens carry more caligids than those fish cultured with shade. In other words, artificial manipulation of light conditions at net-pen sites may be effective in reducing infection levels of $C$. sclerotinosus on individual red seabream farmed. This caligid is also known as a parasite of red seabream farmed in Korea (Venmathi Maran, Oh, et al. 2012).

A copepodid of unidentified species of 'Caligoida' (originally reported also as 'Ergasilus sp.') was recorded from the skin of one of the red seabream larvae produced at a hatchery (Yamashita 1980, 1981). Currently, the order Caligoida has been regarded as invalid (Kabata 1979), and according to Yamashita (1981), Ju-shey Ho (California State University, Long Beach, CA, USA) identified the specimen as belonging to the Caligidae (misspelled as 'Caligoidae' in Yamashita 1981) or Pennellidae. No discovery of the adult of this unidentified species has so far been made from red seabream or other marine fish.

Two species of parasitic copepods have been reported from blackhead seabream culture in Japan: they are Caligus latigenitalis and Alella macrotrachelus. Our knowledge of $C$. latigenitalis is limited only to the morphology of its adult, copepodid and chalimus stages (Izawa and Choi 2000; Izawa 2004), and no information is available on its ecology and host-parasite relationships at fish farms. In contrast, A. macrotrachelus was well studied for its seasonal occurrence and maturation, larval development, and pathogenicity (Kawatow et al. 1980; Muroga et al. 1981). The species is found on the gills of farmed fish: the prevalence is usually high (almost $100 \%$ ) but the mean intensity fluctuates seasonally with two peaks (about 15 copepods per fish) in both mid-winter and early summer (Muroga et al. 1981). Mature females with egg sacs are observed throughout the year, but eggs do not hatch in mid- 
winter (below $12^{\circ} \mathrm{C}$ ) and mid-summer (higher than $22-23^{\circ} \mathrm{C}$ ). It has one naupliar, one copepodid, and four chalimus stages in its development (Kawatow et al. 1980). Interestingly, infection levels of $A$. macrotrachelus at fish farms near a river mouth are much lower than those at fish farms near the open sea, thus freshwater discharge from rivers has been suggested to reduce the survival of infective copepodids (Muroga et al. 1981). The parasite feeds on the host's gill tissue and erythrocytes, and induces hyperplasia, oedema and haemorrhage in the gill lamellae. While it was an important parasite in past intensive blackhead seabream culture, it is not problematic now, because the current production of the fish remains low.

\section{Copepod infecting Pacific bluefin tuna}

Commercial culture of Pacific bluefin tuna (Thunnus orientalis) (Scombridae) has a short history in Japan, where it substantially started in the 1990s and produced $9639 \mathrm{mt}$ in 2012 (Statistics of fisheries 2014).

No systematic survey of parasitic copepods infecting farmed Pacific bluefin tuna has been conducted, and to date there is only one record of Caligus macarovi (Nagasawa 2011). This caligid is not specific to Pacific bluefin tuna but has been reported from various actinopterygian fish, especially from Pacific saury (Cololabis saira). Because Pacific saury migrates to the waters near the farming site of Pacific bluefin tuna, infective larvae produced from C. macarovi parasitic on Pacific saury have been suggested to be the source of infection at fish farms (Nagasawa 2011).

\section{Copepods infecting Japanese pufferfish}

Despite its current decline in aquaculture production, Japanese pufferfish (Takifugu rubripes) is still one of the important maricultured fish in Japan. Its mean annual production remained over $4000 \mathrm{mt}$ in 2008-2012 (Statistics of fisheries 2014).

Three species of parasitic copepods (two caligids and one lernaeopodid) are known to infect farmed Japanese pufferfish (Ogawa and Inouye 1997). The two caligids were previously reported as Pseudocaligus fugu and Caligus fugu (Ogawa and Inouye 1997), for which the current valid names are $C$. fugu and C. lagocephalus, respectively (Özak et al. 2013). Also, the lernaeopodid was earlier reported as Neobrachiella hugu (Ogawa and Inouye 1997), but its current valid name is Parabrachilella hugu (see Piasecki et al. 2010).

Caligus fugu is a serious pest forming a threat to Japanese pufferfish culture (Ohtsuka et al. 2009; Venmathi Maran et al. 2011). Copepods heavily infect the body surface of farmed fish and cause skin lesions. Secondary bacterial infections are closely associated with such heavy infections and can result in significant mortalities (Ohtsuka et al. 2009). This caligid has two naupliar, one copepodid, and four chalimus stages in its development. It takes nine days to develop from copepodid to adult at about $20^{\circ} \mathrm{C}$ (Ohtsuka et al. 2009). While several treatment methods have been tried to control C. fugu (Hirazawa et al. 2001; Tensha and Momoyama 2006), the results were not successful. A review compiled by Venmathi Maran et al. (2011) is useful to understand the biology of $C$. fugu, including its geographical distribution, host specificity, development and life cycle, seasonal occurrence, impact on hosts, and control. 
In contrast to $C$. fugu, there is limited information on C. lagocephalus and P. hugu parasitic on farmed Japanese pufferfish. These two copepods infect the host's buccal cavity wall. Although there are no data on the seasonal occurrence of C. lagocephalus, the prevalence of $P$. hugu increases with growth of its host and is constantly high (almost 100\%) in the second-year cultured fish (Ogawa and Inouye 1997).

\section{Copepod infecting filefish}

Two species of filefish (Monacanthidae) are maricultured in Japan: threadsail filefish (Stephanolepis cirrhifer) and black scraper (Thamnaconus modestus). Although no statistics are available, their aquaculture production has been increasing in recent years.

Peniculus minuticaudae is a copepod that has been recently recognized as an important parasite of farmed filefish (Nagasawa, Fukuda, et al. 2011; Minami et al. 2012). Copepods are found attached to the fin rays: they occur mainly on the pectoral and second dorsal fins. Up to 90 and 123 copepods were recorded from an individual threadsail filefish and black scraper, respectively (Nagasawa, Fukuda, et al. 2011). Globally, pennellid copepods parasitic on farmed marine fish are quite rare (see Johnson et al. 2004): in addition to P. minuticaudae, only one other species of pennellid, Haemobaphes disphaerocephalus, is known to have accidentally infected Atlantic salmon cultured off the Pacific coast of Canada (Kent et al. 1997). Among pennellid copepods, P. minuticaudae is exceptional in being able to complete its life cycle without needing an intermediate host or changing hosts: the hatched infective copepodid directly finds its host (filefish), becomes adult after four chalimus stages, and reproduces on the same host (Ismail et al. 2013). This simple direct life cycle has enabled the species to establish self-recruiting populations in net pens at fish farms. Heavy infection causes damage in the host's fin membrane, but no other signs are known (Nagasawa, Fukuda, et al. 2011). No control or treatment is conducted at present at fish farms. Recently, this parasite has also been discovered in Korean filefish culture (Venmathi Maran, Moon, et al. 2012, 2014).

\section{Copepods infecting bastard halibut}

Despite the importance of bastard halibut (Paralichthys olivaceus) (Paralichthyidae) as an aquaculture species in Japan (mean annual production: $3879 \mathrm{mt}$ in 2008-2012, Statistics of fisheries 2014), our knowledge of its parasitic copepods is very limited. Ho (2000) listed Lepeophtheirus paralichthydis as a causative agent inducing mortalities of farmed bastard halibut. No other report has been published on this caligid occurring at fish farms.

Biacanthus pleuronichthydis was found on the body surface of wild-caught broodstock candidates of bastard halibut which had been transported to a governmental hatchery (Nagasawa, Tang, et al. 2011). Each fish was found to carry a single copepod. Treatment using $10 \%$ saline water bath for five minutes was effective to remove the copepods from infected fish. 


\section{Parasitic copepods of marine fish cultured in subtropical waters}

Although groupers (Epinephelus spp.) (Serranidae) are farmed in coastal waters of the Ryukyu Islands, southern Japan, no published information is yet available on copepods infecting these fish.

\section{Conclusion and future study}

Based on the literature published between 1960 and 2014, this review compiles information on the copepods infecting marine fish cultured or held as broodstock at governmental hatcheries in Japan and reveals that a total of 20 species of parasitic copepods have been reported from these fish. More than half (12 species, 60\%) of them are caligid sea lice. Not all of these sea lice are commercially important (e.g. $L$. salmonis and $C$. orientalis in both coho salmon and rainbow trout cultures; C. macarovi in Pacific bluefin tuna farming), but due to their high level of infection and impact on individual host fish, three species of Caligus (C. fugu, C. sclerotinosus and $C$. longipedis) are regarded as serious pests in the recent aquaculture of Japanese pufferfish, red seabream and striped jaw, respectively. These sea lice are all skin parasites. As proved in other caligids, they appear to feed on the host's epidermal tissues and blood, and at higher levels of infection, their attachment and feeding activities can cause skin lesions (Fukuda 2001; Ohtsuka et al. 2009; Tanaka et al. 2013). Heavily infected fish may develop secondary bacterial infections, which can result in mortalities and economic losses (Ohtsuka et al. 2009; Tanaka et al. 2013).

Peniculus minuticaudae is also an important parasite in Japanese finfish mariculture. Because of its peculiar direct (= one-host) life cycle (Ismail et al. 2013), the species has already established its populations utilizing filefish as hosts in net pens in a wide area of western Japan (Nagasawa, Fukuda, et al. 2011; Minami et al. 2012) and has the potential to become a serious pest with further development of filefish culture.

Much remains to be studied on the biology and host-parasite relationships of the reported parasitic copepods and their impacts on host fish. This is especially true for the four species (C. fugu, C. sclerotinosus, C. longipedis, and P. minuticaudae), which are the most important parasitic copepods in the current Japanese mariculture. It is also necessary to study various aspects of the biology of two sea lice, L. paralichthydis and C. macarovi, parasitic respectively on farmed bastard halibut and Pacific bluefin tuna, because, for each, only one record is present of an individual sea louse from farmed fish (Ho 2000; Nagasawa 2011).

No parasitic copepod has been reported from fish farmed in the subtropical Ryukyu Islands, which clearly reflects the lack of any surveys conducted on these parasites there. Because many species of sea lice have been found from fish in Taiwan near the Ryukyu Islands (Ho and Lin 2004), some of them are expected to occur in the latter region, as well. For example, groupers are known to harbour three species of caligids (Lepeophtheirus epinepheli, Caligus rotundigenitalis and Caligus sp.) in Taiwanese waters (Ho and Lin 2004), and these species may occur on groupers cultured in the Ryukyu Islands. It is desirable to examine farmed fish for parasitic copepods in the Ryukyu Islands.

With increasing WT caused by global warming, subtropical and tropical species of parasitic copepods may invade Japanese waters. Among such copepods, Caligus 
epidemicus (Caligidae) is a potential pathogenic parasite in Japanese mariculture, because this species is not host-specific (36 species of actinopterygian fish in 17 families and five orders are known as hosts) and causes disease problems and mortality (Nagasawa 2013). While it is widely distributed in tropical and subtropical waters of the Indo-West Pacific region (Nagasawa 2013), it has not yet been found in Japan.

When two species of sea lice, C. lalandei and C. sclerotinosus, were unexpectedly discovered respectively from farmed amberjacks and red seabream in Japan, Ho et al. $(2001,2004)$ discussed their possible of origin and considered one possibility that $C$. lalandei and C. sclerotinosus had been introduced to Japan, individually, along with imported juvenile greater amberjack from Hainan and red seabream from Hong Kong (see also Ho and Lin 2004, pp. 334-335). Actually, numerous greater amberjack juveniles are imported every year as seeds for farming from southern China to Japan (Yamashita et al. 2013), but no information is available on parasitic copepods of these imported juveniles. Moreover, farmed bastard halibut are abundantly (e.g. $5549 \mathrm{mt}$ in 2005) transported alive from Korea to Japan (Yoo and Yamao 2007), but nothing is known about their parasitic copepods. Thus, it is necessary to conduct parasitological investigations of the imported fish from the viewpoint of international transfer and introduction of parasites and for prevention of their spreading.

In Japan, the freshwater bath is commonly employed to reduce infection levels of copepods parasitic on farmed marine fish. However, its efficacy is uncertain, and since copepods re-infect farmed fish soon after a freshwater bath, fish farmers have to repeat it. Studies are needed to develop more efficient treatments and management strategies for controlling parasitic copepods.

\section{Acknowledgements}

I thank Masato Aritaki, Fukuyama University, for information on the pathogenicity and control of $L$. longiventralis. I am also grateful to two anonymous reviewers for constructive comments on the manuscript.

\section{Disclosure statement}

No potential conflict of interest was reported by the author(s).

\section{References}

Boxshall GA, Defaye D, editors. 1993. Pathogens of wild and farmed fish: sea lice. Chichester: Ellis Horwood.

Choe M-K, Kim I-H. 2010. Redescriptions of two morphologically confusing sea lice Caligus aesopus Wilson, 1921 and C. spinosus Yamaguti, 1939 (Copepoda: Siphonostomatoida: Caligidae) parasitic on amberjacks (Seriola spp.) from Korea. Zootaxa. 2483:23-34.

Cruz-Lacierda ER, Yamamoto A, Nagasawa K. 2011. Seasonal occurrence of Caligus spinosus and Parabrachiella seriolae (Copepoda) parasitic on cage-cultured yellowtail (Seriola quinqueradiata) at a fish farm in western Japan. Bull Eur Ass Fish Pathol. 31:58-65.

Egusa S. 1983. Disease problems in Japanese yellowtail, Seriola quinqueradiata, culture: a review. Rapp P-v Réun Cons int Explor Mer. 182:10-18. 
Froese R, Pauly D 2014. FishBase. World Wide Web electronic publication [Internet]. [cited 2014 Sep 10]. Available from: www.fishbase.org

Fujita S, Yoda M, Ugajin I. 1968. Control of an ectoparasitic copepod, Caligus spinosus Yamaguti, on the cultured adult yellowtail. Fish Pathol. 2:122-127. [In Japanese.]

Fukuda Y. 1999. Diseases of marine fishes and shellfishes cultured in Oita Prefecture diagnosed from 1980 to 1997. Bull Oita Inst Mar Fish Sci. 2:41-73. [In Japanese.]

Fukuda Y. 2001. Skin caligosis of striped jack. Yoshoku. 38:21-22. [In Japanese.]

Hirazawa N, Oshima S-I, Hata K. 2001. In vitro assessment of the antiparasitic effect of caprylic acid against several fish parasites. Aquaculture. 200:251-258.

Ho J-S. 2000. The major problem of cage aquaculture in Asia relating to sea lice. In: Liao IC, Lin CK, editors. Cage aquaculture in Asia: proceedings of the First International Symposium on Cage Aquaculture in Asia. Manila: Asian Fish Society; p. 13-19.

Ho J-S, Gómez S, Ogawa K, Aritaki M. 2004. Two species of parasitic copepods (Caligidae) new to Japan. Syst Parasitol. 57:19-34.

Ho J-S, Lin C-L. 2004. Sea lice of Taiwan (Copepoda: Siphonostomatoida: Caligidae). Keelung: The Sueichan Press.

Ho J-S, Nagasawa K. 2001. Why infestation by Lepeophtheirus salmonis (Copepoda: Caligidae) is not a problem in the coho salmon farming industry in Japan. J Crust Biol. 21:954-960.

Ho J-S, Nagasawa K, Kim I-H, Ogawa K. 2001. Occurrence of Caligus lalandei Barnard, 1948 (Copepoda, Siphonostomatoida) on amberjacks (Seriola spp.) in the western North Pacific. Zool Sci. 18:423-431.

Ismail N, Ohtsuka S, Venmathi Maran BA, Tasumi S, Zaleha K, Yamashita H. 2013. Complete life cycle of a pennellid Peniculus minuticaudae Shiino, 1956 (Copepoda: Siphonostomatoida) infecting cultured threadsail filefish, Stephanolepis cirrhifer. Parasite. 20:42.

Izawa K. 1969. Life history of Caligus spinosus Yamaguti, 1939 obtained from cultured yellowtail, Seriola quinqueradiata T. \& S. (Crustacea: Caligoida). Rep Fac Fish, Pref Univ Mie. 6:127-157.

Izawa K. 2004. The copepodid and two chalimus stages of Caligus latigenitalis Shiino, 1954 (Copepoda, Siphonostomatoida, Caligidae), parasitic on Japanese black sea bream, Acanthopagrus schlegeli. Cont Biol Lab Kyoto Univ. 29:329-341.

Izawa K, Choi K-H. 2000. Redescription of Caligus latigenitalis Shiino, 1954 (Copepoda, Siphonostomatoida, Caligidae), parasitic on Japanese black sea bream, Acanthopagrus schlegeli (Bleeker, 1854). Crustaceana. 73:995-1005.

Johnson SC, Albright LJ. 1992. Comparative susceptibility and histopathology of the response of naive Atlantic, chinook and coho salmon to experimental infection with Lepeophtheirus salmonis (Copepoda: Caligidae). Dis Aquat Org. 14:179-193.

Johnson SC, Treasurer JW, Bravo S, Nagasawa K, Kabata Z. 2004. A review of the impact of parasitic copepods on marine aquaculture. Zool Stud. 43:229-243.

Jones S, Beamish R, editors. 2011. Salmon lice: an integrated approach to understanding parasite abundance and distribution. Chichester: Wiley-Blackwell.

Kabata Z. 1979. Parasitic Copepoda of British fishes. London: The Ray Society.

Kawatow K, Muroga K, Izawa K, Kasahara S. 1980. Life cycle of Alella macrotrachelus (Copepoda) parasitic on cultured black sea-bream. J Fac Appl Sci, Hiroshima Univ. 19:190-214. [In Japanese with English abstract.]

Kent ML, Whitaker DJ, Mora JDW, Kabata Z. 1997. Haemobaphes disphaerocephalus, an accidental parasite of seawater pen-reared Atlantic salmon. Can Vet J. 38:110-111.

Kubota SS, Takakuwa M. 1963. Studies on the diseases of marine-culture fishes-I. General decsription and preliminary discussion of fish diseases at Mie Prefecture. J Fac Fish, Pref Univ Mie. 6:107-124. 5 pls. [In Japanese with English abstract.] 
Minami T, Kanematsu M, Iwata K, Nakanishi K, Yamashita A, Miyoshi Y, Fukuda Y, Yoshida T. 2012. Occurrences of diseases in thread-sail filefish in western part of Japan. Fish Pathol. 47:111-113. [In Japanese with English abstract.]

Muroga K, Kawatow K, Ichizono H. 1981. Infestation by Alella macrotrachelus (Copepoda) of cultured black sea-bream. Fish Pathol. 16:139-144. [In Japanese with English abstract.]

Mushiake K. 1996. Studies on technical development of brood stock management in striped jack and yellowtail. Spec Sci Res Rep, Japan Sea-Farming Assoc. 9:1-62. [In Japanese with English abstract.]

Nagasawa K. 2004. Sea lice, Lepeophtheirus salmonis and Caligus orientalis (Copepoda: Caligidae), of wild and farmed fish in sea and brackish waters of Japan and adjacent regions: a review. Zool Stud. 43:173-178.

Nagasawa K. 2011. Caligus macarovi (Copepoda, Caligidae) from Pacific bluefin tuna, Thunnus orientalis, cultured in Japan. Crustaceana. 84:1145-1147.

Nagasawa K. 2013. Caligus epidemicus (Copepoda: Caligidae), a pathogenic sea louse of wild and captive fish in Indo-West Pacific region: a review. Bull Hiroshima Univ Mus. 5:71-86.

Nagasawa K, Fukuda Y. 2011. Two specis of Caligus (Copepoda: Caligidae) from amberjacks (Seriola spp.) cultured in Oita Prefecture, Kyushu, western Japan. Biosphere Sci. 50:49-53.

Nagasawa K, Sakamoto S. 1993. Infection of the salmon louse Lepeophtheirus salmonis (Copepoda: Caligidae) on seawater-farmed salmonids in northern Honshu, Japan. Fish Pathol. 28:143-144.

Nagasawa K, Takaya Y. 2008. Unusual heavy infection with Acanthochondria priacanthi (Copepoda, Chondracanthidae) on adult sailfin sandfish Arctoscopus japonicus from the Pacific Ocean off southwestern Hokkaido. Biogeography. 10:17-22.

Nagasawa K, Umino T, Uyeno D, Ohtsuka S, Koizumi H. 2008. Infection with the parasitic copepod Clavella parva (Lernaeopodidae) in gold-eye rockfish Sebastes thompsoni broodstock in Japan. Fish Pathol. 43:55-60.

Nagasawa K, Fukuda Y, Tanaka S. 2011. Infection with Peniculus minuticaudae (Copepoda: Pennellidae) on threadsail filefish (Stephanolepis cirrhifer) and black scraper (Thamnaconus modestus) cultured in Japan. Biosphere Sci. 50:43-47.

Nagasawa K, Tang D, Tamego T. 2011. Biacanthus pleuronichthydis (Copepoda: Taeniacanthidae) from a new fish host Paralichthys olivaceus (Pleuronectiformes: Paralichthyidae) in the Seto Inland Sea, Japan. Biogeography. 13:41-43.

Ogawa K. 1992. Caligus longipedis infection of cultured striped jack, Pseudocaranx dentex (Teleostei: Carangidae) in Japan. Fish Pathol. 27:197-205.

Ogawa K, Inouye K. 1997. Parasites of cultured tiger puffer (Takifugu rubripes) and their seasonal occurrences, with descriptions of two new species of Gyrodactylus. Fish Pathol. 32:7-14.

Ogawa K, Yokoyama H. 1998. Parasitic diseases of cultured marine fish in Japan. Fish Pathol. 33:303-309.

Ohtsuka S, Takami I, Venmathi Maran BA, Ogawa K, Shimono T, Fujita Y, Asakawa M, Boxshall GA. 2009. Developmental stages and growth of Pseudocaligus fugu Yamaguti, 1936 (Copepoda: Siphonostomatoida: Caligidae) host specific to puffer. J Nat Hist. 43:1779-1804.

Ono S. 1984. On Brachiella seriolae parasitic on cultured yellowtail, Seriola quinqueradiata T \& S., in Oita Prefecture. Sci Rep Oita Pref Fish Exp Stn. 11:86-90. [In Japanese.]

Özak AA, Demirkale İ, Boxshall GA, Etyemez M. 2013. Parasitic copepods of the common sole, Solea solea (L.), from the Eastern Mediterranean coast of Turkey. Syst Parasitol. 86:173-185.

Piasecki W, Młynarczyk M, Hayward CJ. 2010. Parabrachiella jarai sp. nov. (Crustacea: Copepoda: Siphonostomatoida) parasitic on Sillago sihama (Actinopterygii: Perciformes: Sillaginidae). Exp Parasitol. 125:55-62. 
Pike AW, Wadsworth SL. 1999. Sea lice on salmonids: their biology and control. Adv Parasitol. 44:233-337.

Skern-Mauritzen R, Torrissen O, Glover KA. 2014. Pacific and Atlantic Lepeophtheirus salmonis (Krøyer, 1838) are allopatric subspecies: Lepeophtheirus salmonis salmonis and L. salmonis oncorhynchi subspecies novo. BMC Genetics. 15:32.

Statistics of Fisheries. 2014. Statistics of fisheries and aquaculture production. Tokyo: Ministry of Agriculture, Forestry and Fisheries. [In Japanese.]

Tanaka S, Yamamoto S, Ogawa K. 2013. The occurrence of Caligus sclerotinosus (Caligidae) infection in cultured red sea bream Pagrus major and involvement of phototaxis in fish-tofish transfer of the adults. Fish Pathol. 48:75-80.

Tensha K, Momoyama K. 2006. Effects of hydrogen peroxide solution and diluted seawater on detaching the parasitic copepod Pseudocaligus fugu from the juvenile tiger puffer Takifugu rubripes. Bull Yamaguchi Pref Fish Res Ctr. 4:163-166. [In Japanese with English abstract.]

Urawa S, Kato T. 1991. Heavy infections of Caligus orientalis (Copepoda: Caligidae) on caged rainbow trout Oncorhynchus mykiss in brackish water. Fish Pathol. 26:161-162.

Urawa S, Kato T, Kumagai A. 1998. A status of Lepeophtheirus salmonis (Copepoda: Caligidae) on seawater-cultured coho salmon (Oncorhynchus kisutch) and rainbow trout (O. mykiss) in Japan. Bull Natl Salmon Resources Center. 1:35-38.

Venmathi Maran BA, Moon SY, Oh S-Y, Soh HY, Myoung J-G. 2012. Redescription of two pennellids (Copepoda, Siphonostomatoida) from Korea with a key to species of Peniculus von Nordmann, 1832. ZooKeys. 243:1-14.

Venmathi Maran BA, Oh S-Y, Choi H-J, Myoung J-G. 2014. Seasonal occurrence and habitat of two pennellids (Copepoda, Siphonostomatoida) infecting marine ranched black scraper and Korean rockfish in Korea. Trop Biomed. 31:362-369.

Venmathi Maran BA, Ohtsuka S, Takami I, Okabe S, Boxshall GA. 2011. Recent advances in the biology of the parasitic copepod Pseudocaligus fugu (Siphonostomatoida, Caligidae), host specific to pufferfishes of the genus Takifugu (Actinopterygii, Tetraodontidae). In: Asakura A, et al. editors. New frontiers in crustacean biology: proceedings of the TCS Summer Meeting; 2009 Sept 20-24; Tokyo. Crust Monogr. 15:31-45.

Venmathi Maran BA, Oh S-Y, Soh HY, Choi HJ, Myoung J-G. 2012. Caligus sclerotinosus (Copepoda: Caligidae), a serious pest of cultured red seabream Pagrus major (Sparidae) in Korea. Vet Parasitol. 188:355-361.

Yamaguti S, Yamasu T. 1960. Two new species of copepods parasitic on Japanese fishes. Publ Seto Mar Biol Lab. 8:137-140. 1 pl.

Yamashita K. 1980. Parasitic Copepoda (Ergasilus sp.) found on the epidermis of the larval fish of red sea bream (Pagrus major). Fish Pathol. 15:91-94. [In Japanese with English abstract.]

Yamashita K. 1981. Correction of the report entitled "The parasite found on the epidermis of the larval fish of red sea bream (Pagrus major)" appeared in Fish Pathology 15: 91-94, 1980. Fish Pathol. 16:55. [In Japanese with English abstract.]

Yamashita A, Kurata O, Takagi S, Wada S. 2013. Information on rearing of great amberjack juveniles in China. Fish Pathol. 48:63-65. [In Japanese.]

Yoo M, Yamao M. 2007. Trend and future prospect of Korean live fish export: a study on export of cultured flatfish toward Japan. J Reg Fish Econ. 47:23-41. [In Japanese with English abstract.] 